\title{
In vitro antimicrobial evaluation of toothpastes with natural compounds
}

\author{
Priscila de Camargo Smolarek ${ }^{1}$, Luis Antonio Esmerino ${ }^{2}$, Ana Cláudia Chibinski ${ }^{1}$, \\ Marcelo Carlos Bortoluzzi ${ }^{1}$, Elizabete Brasil dos Santos ${ }^{1}$, Vitoldo Antonio Kozlowski Junior ${ }^{1}$
}

Correspondence: Dr. Vitoldo Antonio Kozlowski Junior Email: vakozlowski@uepg.br

\author{
'Department of Dentistry, Ponta Grossa State \\ University, Paraná, Brazil, \\ ${ }^{2}$ Department of Clinical Analyses, Ponta Grossa State \\ University, Paraná, Brazil
}

\section{ABSTRACT}

Objectives: This in vitro study evaluated the antimicrobial effects of commercial toothpastes containing natural compounds. Materials and Methods: The study groups were divided based on the natural compound present in the toothpaste composition: Sorbitol (I), tocopherol (II), mint (III), cinnamon/mint (IV), propolis/melaleuca (V), mint/açai (VI), mint/guarana (VII), propolis (VIII), negative control (IX), and the positive control (X). The antimicrobial properties of the toothpastes were tested using the disk diffusion method against oral pathogens: Streptococcus mutans, Pseudomonas aeruginosa, and Enterococcus faecalis. The resulting inhibition halos were measured in millimeters. Results: The data indicated that the bacteria responded differently to the toothpastes $(P<0.0001)$. The diameters of the inhibition halos against $S$. mutans were in decreasing order of efficacy: Propolis/melaleuca $>$ mint/guarana $>$ mint/açai $>$ sorbitol $>$ tocopherol $>$ cinnamon $/ \operatorname{mint}>$ propolis $>\operatorname{mint}(P<0.001$ vs. negative control). E. faecalis showed variable responses to the dentifrices in the following order of decreasing efficacy: Mint/guarana $>$ propolis $>$ sorbitol $>$ mint $/$ açai $>$ tocopherol $>$ cinnamon $/ \operatorname{mint}>\operatorname{mint}=$ propolis $/$ melaleuca $=$ negative control. The product with the highest antimicrobial activity was mint/guarana, which was significantly different than propolis/melaleuca, mint, cinnamon/mint, and tocopherol and negative control $(P<0.001)$. The statistical analysis indicated that propolis, sorbitol, and mint/açai did not show any differences compared to mint/guarana $(P>0.05)$ and positive control $(P>0.05)$. $P$. aeruginosa was resistant to all dental gels tested including positive control. Conclusion: The toothpastes with natural compounds have therapeutic potential and need more detailed searches for the correct clinic therapeutic application. The results from this study revealed differences in the antimicrobial activities of commercial toothpastes with natural compounds.

Key words: Antimicrobial activity, dental gels, dentifrices, natural products, toothpastes

\section{INTRODUCTION}

The tendency among world consumers, to seek natural products for a healthier lifestyle has increased the use these compounds in food, cosmetic, and pharmaceutical products. ${ }^{[1]}$ The marketing of these products contributes to an increasing in consumption, and natural dental products are also targets of such marketing with a wide variety of products available in all world. The consumer is often induced to buy these products without being aware of their efficacy ${ }^{[2]}$ with the presence of natural compounds by itself does not guarantee their antibacterial activity in the formulation, for example.

This is particularly important characteristic for toothpastes, which are expected to help in the control of the biofilm, including cariogenic and opportunistic bacteria, such as Streptococcus mutans, Enterococcus faecalis, and Pseudomonas aeruginosa. ${ }^{[3]}$

Toothpastes have a wide range of pharmaceutical compositions and consistencies, including gel form

This is an open access article distributed under the terms of the Creative Commons Attribution-NonCommercial-ShareAlike 3.0 License, which allows others to remix, tweak, and build upon the work non-commercially, as long as the author is credited and the new creations are licensed under the identical terms.

For reprints contact: reprints@medknow.com

How to cite this article: de Camargo Smolarek P, Esmerino LA, Chibinski AC, Bortoluzzi MC, dos Santos EB, Kozlowski VA. In vitro antimicrobial evaluation of toothpastes with natural compounds. Eur $\mathrm{J}$ Dent 2015;9:580-6.

DOI: $10.4103 / 1305-7456.172632$ 
that often incorporates natural compounds. Among the most common natural compounds in toothpastes is mint, which is used mainly for flavor, ${ }^{[4]}$ species of the genus. Mentha are also used for different medicinal purposes as an antiseptic, anti-inflammatory, and antimicrobial agent. ${ }^{[1,2]}$

The species cinnamon (Cinnamomum cassia) has an important antimicrobial activity due to the presence of cinnamaldehyde ${ }^{[3]}$ while the sugar alcohol - sorbitol is found naturally in different plants; it has a bacteriostatic property, ${ }^{[5]}$ but is considering just a softener and texturing agent in many natural herbal dentifrices. $^{[4]}$

The use of the açai species (Euterpe oleracea and E. precatoria Mart.) is very promising. ${ }^{[6,7]}$ They are considered important nutraceuticals agents, and show significant antioxidant properties due to their rich content of flavonoids ${ }^{[7]}$ and anthocyanins, ${ }^{[8]}$ which are known for their anticarcinogenic, anti-inflammatory, and antimicrobial properties. ${ }^{[9,10]}$

The specie Paullinia cupana (guarana) can be used as an antibacterial and antioxidant agent, ${ }^{[11]}$ while the Melaleuca alternifolia (tea tree) have excellent medicinal properties, showing anticarcinogenic, anti-inflammatory, antifungal, antiviral, and antibacterial activities. ${ }^{[12]}$

Due to the presence of flavonoids and phenolic acids, the propolis species have anti-inflammatory, cytotoxic, antiatherogenic, antioxidant, and antimicrobial activities too. ${ }^{[13]}$

Tocopherols are Vitamin E precursors, belong to the terpenoid group, and they are vitamins, antioxidants, modulators of immune function, and regulators of cell differentiation and proliferation. ${ }^{[14]}$

Due to the wide variety of plants with activities relevant to dentistry and their presence in dental products, this study aimed to evaluate the in vitro antimicrobial activities of toothpastes containing natural compounds.

\section{MATERIALS AND METHODS}

\section{Selection and classification of toothpastes for analysis}

A total of 11 toothpastes with natural compounds were acquired in drugstores and supermarkets in Ponta Grossa, Paraná, Brazil. Three dentifrices were excluded since they have ingredients with well-known antimicrobial activities that they were not the natural compounds. The remaining eight products composed the sample of this study. The study groups were divided based on the natural compound present in the toothpaste composition: Sorbitol (I), tocopherol (II), mint (III), cinnamon/mint (IV), propolis/melaleuca (V), mint/açai (VI), mint/ guarana (VII), and propolis (VIII). The group IX was a toothpaste specially formulated without antimicrobial agents with $1 \%$ hydroxyethylcellulose (negative control) ${ }^{[15]}$ and the group $X$ was a dental gel with triclosan and formaldehyde in your pharmaceutical formulation (positive control) [Table 1 and Figure 1].

\section{Microorganisms}

The bacterial strains S. mutans (ATCC 25175), $P$. aeruginosa (ATCC 27853), and E. faecalis (ATCC 29212) were used for the antimicrobial analysis. The mediums were blood agar (S. mutans) and Mueller Hinton agar (P. aeruginosa and E. faecalis) described previably. ${ }^{[16,17]}$

\section{Microbiological technical for tests}

The disk diffusion method was used for the experiment. The samples of toothpaste and saline solution (1:3) were prepared. Inert paper discs of uniform size were embedded in this solution and places in the plates after inoculation. All plates were done in triplicate, and they were incubated at $35-37^{\circ} \mathrm{C}$ for $16-18 \mathrm{~h}$. At the end of the incubation period, the inhibition halos were measured in millimeters $(\mathrm{mm}) .^{[15,18]}$

\section{Statistical analysis}

The results were organized and analyzed statistically with the program SPSS ${ }^{\circledR} 11.0$, SPSS Inc., Chicago, IL, USA. The multiple comparison tests between treatments versus control groups were evaluated by one-way analysis of variance (ANOVA), and the posttests Bonferroni and Tukey with a significance level at $5 \%$. The graphics were performed using the software GraphPad Prism ${ }^{\circledR} 4.00$, GraphPad Software Inc., San Diego, CA, USA.

\section{RESULTS}

All samples the toothpastes tested were classified in dental gels following pharmacotechnical principles [Figure 1]. ANOVA indicated that the bacteria responded differently to the dental gels $(P<0.0001)$. A post-hoc Tukey's test showed that $P$. aeruginosa had a different response compared to S. mutans $(P<0.0001)$ and to E. faecalis $(P<0.0001)$. The Bonferroni's post-hoc test showed variable responses to the dental gels $(P<0.0001)$ in $S$. mutans 


\begin{tabular}{|c|c|c|c|c|}
\hline $\begin{array}{l}\text { Number } \\
\text { identification }\end{array}$ & $\begin{array}{l}\text { Experimental } \\
\text { group }\end{array}$ & Name & $\begin{array}{l}\text { Ingredients as listed on packages with chemistry/IUPAC/name/ } \\
\text { description }\end{array}$ & Manufacturer \\
\hline I & Sorbitol & Colgate $\mathrm{Gel}^{\circledR}$ & $\begin{array}{l}\text { Sorbitol, dental type silica, demineralized water, PEG-12, } \\
\text { sodium lauryl sulfate, sodium carboxymethyl cellulose, } \\
\text { tetrasodium pyrophosphate, sodium saccharin, sodium } \\
\text { fluoride, FD } 7 \text { C Blue number } 1 \mathrm{Cl} 42090 \text { (dihydrogen (ethyl) } \\
\text { [4-[4-[ethyl (3-sulphonatobenzyl)]amino]-2'- } \\
\text { sulphonatobenzhydrylidene] cyclohexa-2,5-dien-1-ylidene] } \\
\text { (3-sulphonatobenzyl) ammonium, disodium salt) }\end{array}$ & $\begin{array}{l}\text { Colgate- } \\
\text { Palmolive, Brazi }\end{array}$ \\
\hline II & Tocopherol & $\begin{array}{l}\text { Gel com } \\
\text { Vitamin E }\end{array}$ & $\begin{array}{l}\text { Sorbitol, hydrated silica, water, PEG-12, sodium lauryl sulfate, } \\
\text { sodium carboxymethyl cellulose, tetrasodium pyrophosphate, } \\
\text { sodium saccharin, sodium fluoride, Vitamin E, FD } 7 \text { C Blue number } \\
1 \mathrm{Cl} 42090 \text { (dihydrogen (ethyl)[4-[4-[ethyl (3-sulphonatobenzyl)] } \\
\text { amino]-2'-sulphonatobenzhydrylidene] cyclohexa-2,5-dien-1-ylidene] } \\
\text { (3-sulphonatobenzyl) ammonium, disodium salt) }\end{array}$ & $\begin{array}{l}\text { Fleming } \\
\text { Manipulações, } \\
\text { Brazil }\end{array}$ \\
\hline III & Mint & $\begin{array}{l}\text { Sensodyne }^{\circledR} \\
\text { Extra fresh }\end{array}$ & $\begin{array}{l}\text { Sodium fluoride, potassium nitrate } 5 \% \text {, sorbitol, acqua } \\
\text { hydrated silica, glycerin, titanium dioxide, cocamidopropyl } \\
\text { betaine, flavor, xanthan gum, sodium hydroxide, sodium } \\
\text { saccharin, Mentha piperita oil, sucralose, aroma }\end{array}$ & $\begin{array}{l}\text { GlaxoSmithKline } \\
\text { Brazil }\end{array}$ \\
\hline IV & Cinnamon/mint & $\begin{array}{l}\text { Sorriso } \\
\text { Whitening } \\
\text { explosion - gel } \\
\text { canela/mint }\end{array}$ & $\begin{array}{l}\text { Sorbitol, acqua, hydrated silica, PEG-12 (PEG } 600 \text { ), } \\
\text { sodium lauryl sulfate, cocamidopropyl betaine, aroma, } \\
\text { cellulose gum, tetrasodium pyrophosphate, sodium fluoride } \\
\text { ( } 1450 \text { ppm), sodium saccharin, polyethylene, CI } 77891 \\
\text { (titanium dioxide), Cl } 16035 \text { (disodium 6-hydroxy-5-' } \\
\text { (2-methoxy-4-sulphonato-m- tolyl) azo[naphthalene-2-sulphonate) }\end{array}$ & $\begin{array}{l}\text { Colgate- } \\
\text { Palmolive, Brazi }\end{array}$ \\
\hline V & $\begin{array}{l}\text { Propolis/ } \\
\text { melaleuca }\end{array}$ & $\begin{array}{l}\text { Natural } \\
\text { propolis } \\
\text { toothpaste } \\
\text { with tea } \\
\text { tree oil }\end{array}$ & $\begin{array}{l}\text { Calcium carbonate, glycerin, acqua, propolis extract, Melaleuca } \\
\text { alternifolia (tea tree) leaf oil, xanthan gum, maltodextrin, Cl } \\
75810 \text { (trisodium (2S-trans)-[18-carboxy-20-(carboxymethyl)- } \\
\text { 13-ethyl-2,3-dihydro-3,7,12,17-tetramethyl-8- } \\
\text { vinyl-21H,23H-porphine-2-propionato (5-)-N21, N22, N23, } \\
\text { N24]cuprate (3-)/chlorophyllin-copper complex) }\end{array}$ & $\begin{array}{l}\text { Comvita, } \\
\text { New Zealand }\end{array}$ \\
\hline VI & Mint/açaí & $\begin{array}{l}\text { Sorriso }^{\circledR} \\
\text { Fresh } \\
\text { menta + açaí }\end{array}$ & $\begin{array}{l}\text { Sorbitol, acqua, hydrated silica, PEG-12 (PEG } 600 \text { ), sodium } \\
\text { lauryl sulfate, cocamidopropyl betaine, aroma, cellulose gum, } \\
\text { tetrasodium pyrophosphate, sodium fluoride (1450 ppm), } \\
\text { sodium saccharin, polyethylene, CI } 77891 \text { (titanium dioxide) }\end{array}$ & $\begin{array}{l}\text { Colgate- } \\
\text { Palmolive, Brazi }\end{array}$ \\
\hline VII & Mint/guaraná & $\begin{array}{l}\text { Sorriso }^{\circledR} \\
\text { Fresh } \\
\text { Menta + } \\
\text { Guaraná }\end{array}$ & $\begin{array}{l}\text { Sorbitol, acqua, hydrated silica, PEG-12 (PEG } 600 \text { ), sodium } \\
\text { lauryl sulfate, cocamidopropyl betaine, aroma, cellulose gum, } \\
\text { tetrasodium pyrophosphate, sodium fluoride (1450 ppm), } \\
\text { sodium saccharin, polyethylene, CI } 77891 \text { (titanium dioxide) }\end{array}$ & $\begin{array}{l}\text { Colgate- } \\
\text { Palmolive, Brazi }\end{array}$ \\
\hline VIII & Propolis & $\begin{array}{l}\text { Sorriso }^{\circledR} \\
\text { Fresh } \\
\text { menta + } \\
\text { própolis }\end{array}$ & $\begin{array}{l}\text { Sorbitol, acqua, hydrated silica, PEG-12 (PEG } 600 \text { ), sodium } \\
\text { lauryl sulfate, cocamidopropyl betaine, aroma, cellulose gum, } \\
\text { tetrasodium pyrophosphate, sodium fluoride ( } 1450 \text { ppm), } \\
\text { sodium saccharin, polyethylene, CI } 77891 \text { (titanium dioxide) }\end{array}$ & $\begin{array}{l}\text { Colgate- } \\
\text { Palmolive, Brazi }\end{array}$ \\
\hline IX & $\begin{array}{l}\text { Negative } \\
\text { control }\end{array}$ & $\begin{array}{l}\text { Negative } \\
\text { gel control }\end{array}$ & $1 \%$ hydroxyethylcellulose gel (Natrosol) & $\begin{array}{l}\text { Fleming } \\
\text { Manipulações, } \\
\text { Brazil }\end{array}$ \\
\hline$x$ & $\begin{array}{l}\text { Positive } \\
\text { control }\end{array}$ & $\begin{array}{l}\text { Close-up }^{\circledR} \\
\text { Fresh } \\
\text { whitening }\end{array}$ & $\begin{array}{l}\text { Sodium fluoride (1500 ppm fluoride lon), water, sorbitol, silica, perlite, } \\
\text { PEG-32 (PEG 1540), sodium lauryl sulfate, flavor, cellulose gum, } \\
\text { sodium saccharin, titanium dioxide, triclosan, formaldehyde, Cl } \\
74160 \text { (29H, 31H-phthalocyaninato (2-)-N29, N30, N31, N32) copper) }\end{array}$ & Unilever, Brazil \\
\hline
\end{tabular}

culture. The diameters of the inhibition halos against S. mutans were, in decreasing order of efficacy: Propolis/melaleuca > mint/guarana > mint/ açai $>$ sorbitol $>$ tocopherol $>$ cinnamon/ mint $>$ propolis $>$ mint $>$ negative control [Figure 2]. $E$. faecalis showed variable responses to the dental gels $(P<0.0001)$ in the following order of decreasing efficacy (diameter of inhibition halo): Mint/guarana $>$ propolis $>$ sorbitol $>$ mint/ açai $>$ tocopherol $>$ cinnamon $/$ mint $>$ mint $=$ propolis $/$ melaleuca $=$ negative control [Figure 3]. The product with the highest antimicrobial activity was mint/ guarana, which was significantly different than propolis/melaleuca $(P<0.001)$, mint $(P<0.001)$, cinnamon/mint $(P<0.001)$, tocopherol $(P<0.001)$, and negative control $(P<0.001)$. The statistical analysis indicated that propolis, sorbitol, and mint/ açai did not show any differences compared to mint/ 


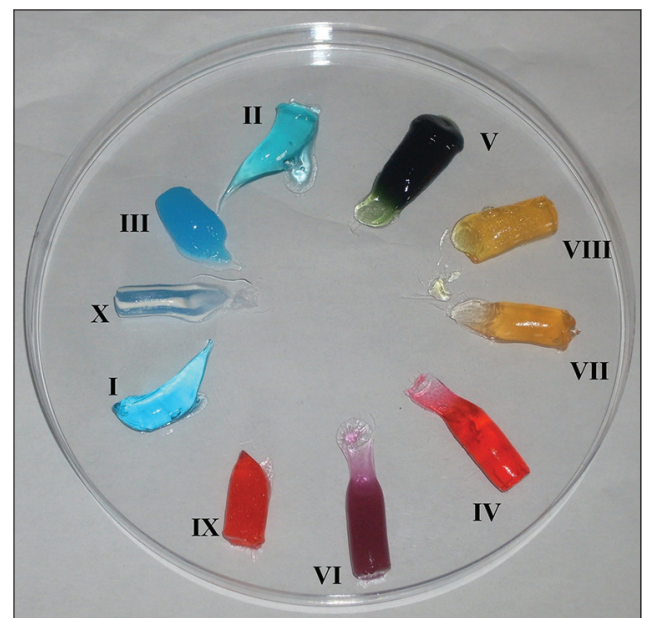

Figure 1: Classification of toothpastes for experimental analysis

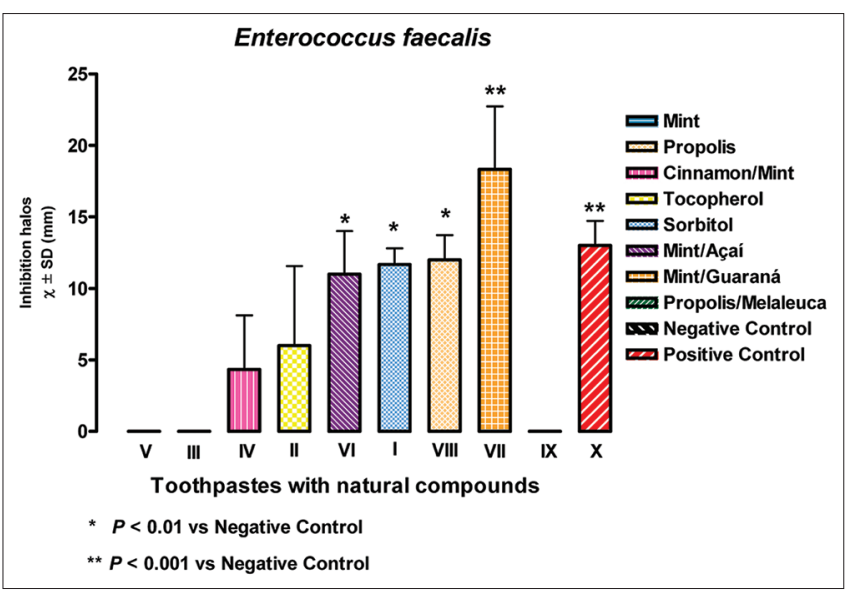

Figure 3: The means and standard deviations of inhibition halos $(X \pm$ standard deviation; millimeter) to toothpaste's antimicrobial activity tested in Enterococcus faecalis culture

guarana $(P>0.05)$ and positive control $(P>0.05)$ but showed statistically significant differences to mint and propolis/melaleuca $(P<0.01)$ [Figure 4]. $P$. aeruginosa was resistant to all dental gels tested including positive control [Figure 5].

\section{DISCUSSION}

The microorganisms tested in this study are intimately related to oral health. S. mutans is one of the mostcommon bacteria found in a dental biofilm, $P$. aeruginosa, and E. faecalis are well-known for their roles in periodontal diseases and endodontic infections. ${ }^{[19]}$ E. faecalis and S. mutans were also evaluated in Mistry's study ${ }^{[20]}$ to compare the antimicrobial activity of common plants in India, and the results showed differences between the microorganisms tested.

In our study, it was observed that there is little information about the concentration of natural

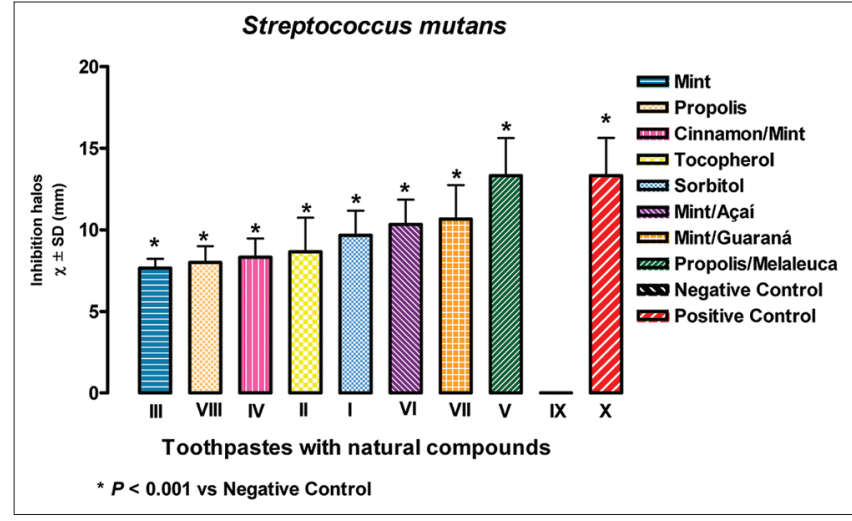

Figure 2: The means and standard deviations of inhibition halos ( $X \pm$ standard deviation; millimeter) to toothpaste's antimicrobial activity tested in Streptococcus mutans culture

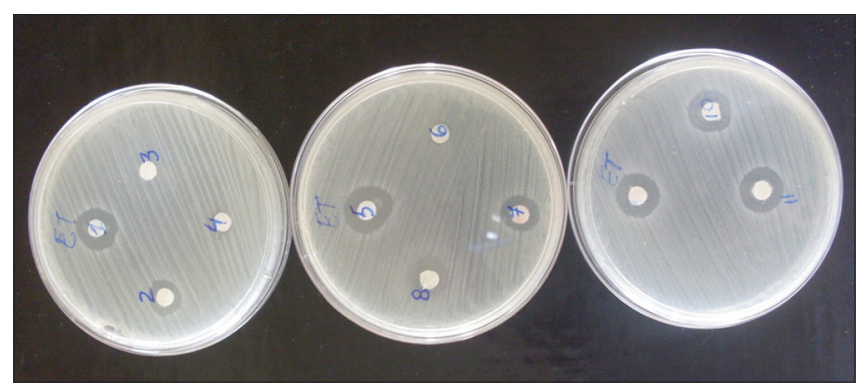

Figure 4: The inhibition halos to toothpastes tested to Enterococcus faecalis culture in Mueller-Hinton agar

compounds on the labels of toothpastes. It is necessary that the qualitative and quantitative composition must be listed on the packages of products for dental hygiene, cosmetics, and perfumes. According to Ganavadiya et al., ${ }^{[21]}$ the most accepted method of oral health maintenance is brushing of teeth, and an adjunct safe toothpaste to help maintaining this condition. Normally, the manufacturer's advertising refers to cosmetic claims and not the safety and therapeutic application of the product, and the consumer trust the publisher who ensures that the product does not cause health damage. This problem could be solved if the manufacturers include in the product labels the qualitative and quantitative compositions of each compound, along with their function and instructions for use, should be included in an explanatory note that accompanies the product. All the products tested not had the information of the concentration of the natural product. Seven marks specified natural products such as flavors and one mark specified natural product such as antimicrobial.

The medicinal use of plants for the treatment, cure, and prevention of diseases is one of the oldest forms of medicinal practice. ${ }^{[22]}$ In a review of the therapeutic use of popular plants for oral diseases, Vieira et al. ${ }^{[19]}$ 


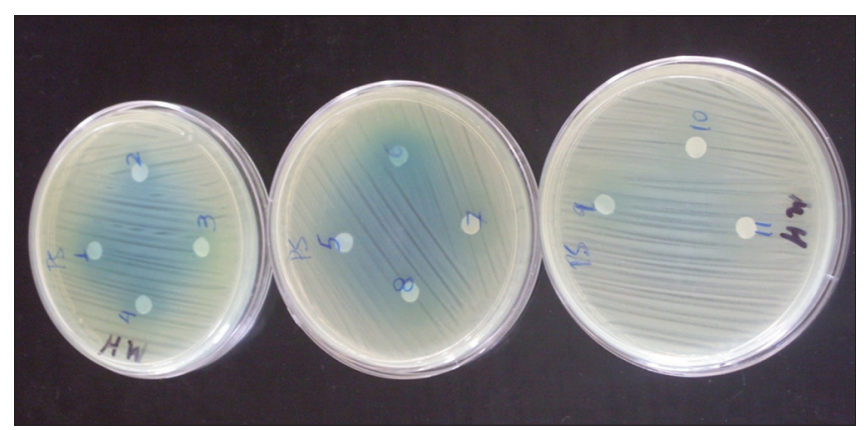

Figure 5: The inhibition halos to toothpastes tested to Pseudomonas aeruginosa culture in Mueller-Hinton agar

identified several studies that evaluated the in vitro antimicrobial activities of plants.

In the present study, different dental gels showed different responses to the tested microorganisms. Mint is often cited as an artificial flavoring component; however, this study showed that mint led to a mean inhibition halo of $7.66 \mathrm{~mm}$ against $S$. mutans. Nogueira et al. ${ }^{[23]}$ observed similar results, with mean inhibition halos of $7 \mathrm{~mm}$ and $9 \mathrm{~mm}$ against $S$. mutans using Mentha piperita and Mentha pulegium extracts, respectively. The results show that mint has antibacterial activity in the dental gels tested; however, based on this and other studies in the literature, further studies should be conducted on the applicability of Mentha sp. extract as coadjuvant in oral health in the future.

Our results indicated that $P$. aeruginosa was resistant to all gels. However, another study found this species to be sensitive to toothpastes with natural compounds such as $M$. piperita, myrrh, ratanhia, salvia, and chamomile. ${ }^{[24]}$ A possible explanation for this could be some difference in the product concentration.

Another natural compound that deserves attention is propolis. Almeida et al. ${ }^{[25]}$ demonstrated that the chemical composition of propolis, especially total flavonoids, is dependent on a variety of factors. A characteristic of propolis is that its concentration of the natural compounds varies depending on the vegetation throughout the region where it originates. Nogueira et al. ${ }^{[23]}$ observed that the samples of propolis extract from three different states in Brazil showed different antibacterial activities against $S$. mutans. The sample from the state of Parana did not show any antibacterial activity; however, those from the states of São Paulo and Minas Gerais had antimicrobial activities though with different minimum inhibitory concentrations (MIC). This variation was confirmed by Siqueira et al. ${ }^{[13]}$ too. These researchers evaluated different concentrations of propolis from the Northeast Brazil and reported that propolis showed important antimicrobial activity on E. faecalis with an inhibition halo of $16 \mathrm{~mm}$ by a $7.5 \%$ solution of red propolis $(150 \mathrm{mg})$. The origin red propolis can be from Cuba, Venezuela, and Brazil. Furthermore, Ercan et al. ${ }^{[26]}$ found a decrease in the plaque index and gingival inflammation in patients who used oral products with propolis. We observed in our data that the dentifrice VIII (propolis) exhibited antimicrobial activity against $S$. mutans and E. faecalis similar the positive controls.

The performances of products VIII (propolis) and $\mathrm{V}$ (propolis/melaleuca) were not similar, even though both gels contain propolis. E. faecalis exhibited resistance to product $\mathrm{V}$ (propolis/melaleuca) and sensitivity to product VIII (propolis). A conflicting result can be justified that the propolis in these two products did not have the same origin and concentration.

It was estimated that there would be sensibility to E. faecalis to both toothpastes regardless of the presence of M. alternifolia. Thosar et al..$^{[27]}$ found that the E. faecalis is sensitive to essential oil the M. alternifolia in contrast to the present study. S. mutans, although sensitive, also showed significantly different responses toward products V and VIII. S. mutans was highly sensitive to product $\mathrm{V}$ (propolis $/$ melaleuca $=13.3 \mathrm{~mm}$ ), and the less responsive to the product VIII (propolis $=8.0 \mathrm{~mm}$ ) compared to the other gels. These results demonstrated the proven antimicrobic activity of M. alternifolia, ${ }^{[28]}$ corroborated by Nogueira et al., ${ }^{[12]}$ who compared antiseptic solutions and reported that $M$. alternifolia product had the strongest antimicrobial activity against $S$. mutans and other microorganisms. These researchers, however, observed that the residual effect was inferior to those of other solutions tested.

It should be noted that the manufacturer of gel $\mathrm{V}$ (propolis/melaleuca) indicated the presence of $M$. alternifolia, while the manufacturer of gel VII (mint/guarana) indicated the presence of P. cupana (guarana). In the present study, P. cupana was the most effective agent against $E$. faecalis and the second most effective for $S$. mutans. This antimicrobial activity against $S$. mutans had been previously reported by Yamaguti-Sasaki et al. ${ }^{[11]}$

Freire et al. ${ }^{[29]}$ observed that $S$. mutans is sensitive to C. cassia (cinnamon) with low MIC values. The product IV (mint/cinnamon) exhibited antimicrobial activity against $S$. mutans and $E$. faecalis but not against 
$P$. aeruginosa, which was resistant to all toothpastes tested. These researchers observed that cinnamon and citronella showed strong antimicrobial activity against $S$. mutans compared to the control.

Products I (sorbitol) and II (tocopherol) also showed antimicrobial activity against $S$. mutans and E. faecalis. The mixed tocopherols are found in several plants and has antioxidant activity. ${ }^{[30]}$ Therefore, it is impossible to relate the antimicrobial activity only to the presence of tocopherol, and it would be necessary to test alpha, beta, gamma, and delta-tocopherol individually. ${ }^{[31]}$ Especially, because Green et al..$^{[32]}$ reported a significant delivery of Vitamin E acetate to the surface of the gingival tissues from the test toothpaste (mean level $=50.7 \mathrm{ppm}$ ) compared to a control dentifrice $(=1.4 \mathrm{ppm})$ and Scott et al. ${ }^{[33]}$ showed that buccal and gingival epitheliums are able to metabolize Vitamin E acetate, to the free form, Vitamin E.

Sorbitol ferments considerably more slowly than saccharose and glucose, and its environmental $\mathrm{pH}$ is often higher than the environmental $\mathrm{pH}$ values of the other two sugars, which prevents demineralization and the consequent formation of dental caries. ${ }^{[34]}$ Besides, different studies have demonstrated a consistent decrease in dental caries, among subjects using sorbitol or xylitol in toothpastes by decreased lactic acid production, enhanced clearance of sugars from the mouth and reduction the levels of $S$. mutans, ${ }^{[35]}$ what it is coherent with the microbiology data obtained. Petersson et al..$^{[36]}$ evaluated four different toothpastes in a 3-year clinical and microbiology study, and these researchers found no significant differences between the experimental groups to caries lesions and number of mutans streptococci and lactobacilli in saliva. However, the patients who used toothpaste with the xylitol-sorbitol mixture showed a lower caries increment as compared with children who used the toothpaste with sorbitol alone.

\section{CONCLUSIONS}

It is suggested that, according to this study and the literature, the toothpastes with natural compounds have therapeutic potential and need more detailed searches for the correct clinic therapeutic application. The results from this study revealed differences in the antimicrobial activities of commercial toothpastes with natural compounds. Further studies on the pharmacological activities such as antifungal, antiviral, and anti-inflammatory effects of the natural compounds are necessary to improve the understanding of the applicability of such products in toothpastes. Furthermore, the clinical, toxicological, and safety tests must be conducted, monitoring the side and idiosyncratic effects, aimed at increasing the implementation of new pharmaceutical formulations using natural products.

\section{Financial support and sponsorship Nil.}

\section{Conflicts of interest}

There are no conflicts of interest.

\section{REFERENCES}

1. Grisi MC, Silva DB, Alves RB, Gracindo LA, Vieira RF. Mint genotypes assessment (Mentha spp) under the conditions of the Federal District, Brazil. Braz J Med Plants 2006;8:33-9.

2. Deschamps C, Monteiro R, Machado MP, Scheer AP, Cocco L, Yamamoto C. Genotype evaluation of Mentha arvensis, Mentha X piperita, Mentha spp. for the production of menthol. Hortic Bras 2013;31:178-83.

3. Pannuti CM, Mattos JP, Ranoya PN, Jesus AM, Lotufo RF, Romito GA. Clinical effect of a herbal dentifrice on the control of plaque and gingivitis: A double-blind study. Pesqui Odontol Bras 2003;17:314-8.

4. Lee SS, Zhang W, Li Y. The antimicrobial potential of 14 natural herbal dentifrices: Results of an in vitro diffusion method study. J Am Dent Assoc 2004;135:1133-41.

5. Nezzal A, Aerts L, Verspaille M, Henderickx G, Redl A. Polymorphism of sorbitol. J Cryst Growth 2009;15:3863-70.

6. Santana MF, Lima AK, Mourão M. Evaluation prospective açaí: Analysis through the orders of patents and references. Rev GEINTEC 2014;4:437-52.

7. Galotta AL, Boaventura MA, Lima LA. Antioxidant and cytotoxic activities of 'Açaí' (Euterpe precatoria Mart.). Quim Nova 2008;31:1427-30.

8. Iaderoza M, Baldini IS, Bovi ML. Anthocyanins from fruits of açaí (Euterpe oleracea, Mart.). Trop Sci 1992;32:41-6.

9. Kuskoski EM, Fett P, Asuero AG. Anthocyanins: Un group of naturales pigments: Isolation, identification and properties. Alimentaria 2002;61:61-74.

10. Alasalvar C, Al-Farsi M, Quantick PC, Shahidi F, Wiktorowicz R. Effect of chill storage and modified atmosphere packing (MAP) on antioxidant activity, anthocyanins, carotenoids, phenolics and sensory quality of ready-to-eat shredded orange and purple carrots. Food Chem 2005;89:69-76.

11. Yamaguti-Sasaki E, Ito LA, Canteli VC, Ushirobira TM, Ueda-Nakamura T, Dias Filho BP, et al. Antioxidant capacity and in vitro prevention of dental plaque formation by extracts and condensed tannins of Paullinia cupana. Molecules 2007;12:1950-63.

12. Nogueira MN, Correia MF, Fontana A, Bedran TB, Spolidorio DM Comparative evaluation "in vivo" effectiveness of Melaleuca oil, chlorhexidine and Listerine on Streptococcus mutans and microorganisms in total saliva. Pesqui Bras Odontopediatria Clin Integr 2013;13:343-9.

13. Siqueira AL, Dantas CG, Gomes MZ, Padilha FF, de Albuquerque RL Jr, Cardoso JC. Study of antibacterial action of propolis hydroalcoholic extract on Enterococcus faecalis. Rev Odontol UNESP 2014;43:359-66.

14. Granado LF, Olmedilla AB, Herrero BC, Blanco NI, Pérez SB, Blázquez GS. In vitro bioaccessbility of carotenoids and tocopherols from fruits and vegetable. Food Chem 2007;102:641-8.

15. Herrera DR, Tay LY, Rezende EC, Kozlowski VA Jr, Santos EB. In vitro antimicrobial activity of phytotherapic Uncaria tomentosa against endodontic pathogens. J Oral Sci 2010;52:473-6.

16. Herrera DR, Tay LY, Kose C Jr, Andrade TM, Rezende EC, Kozlowski VA Jr, et al. Antibacterial effect of the association of calcium hydroxide with iodoform on Enterococcus faecalis and Pseudomonas aeruginosa. Rev Estomatol Herediana 2008;18:5-8. 
17. Santos EB, Slusarz PA, Kozlowski VA Jr, Schwartz JP. Antimicrobial effectiveness of natural products against microorganisms related to bacterial endocarditis. Publicatio UEPG Biol Health Sci 2007;13:67-72.

18. Fosquiera EC, Steffens JP, Reinke SM, Possagno RC, Kozlowski VA Jr, Rezende EC, et al. Effect of propolis on in vitro growth of microorganisms associated with periodontitis in HIV positive patients. Rev Periodontia 2008;18:77-82.

19. Vieira DR, Amaral FM, Maciel MC, Nascimento FR, Libério AS. Plants and chemical constituents used in dentistry: A review of ethnopharmacological studies and evaluation of the "in vitro" antimicrobial activity on oral pathogens. Braz J Med Plants 2014;16:135-67.

20. Mistry KS, Sanghvi Z, Parmar G, Shah S. The antimicrobial activity of Azadirachta indica, Mimusops elengi, Tinospora cardifolia, Ocimum sanctum and $2 \%$ chlorhexidine gluconate on common endodontic pathogens: An in vitro study. Eur J Dent 2014;8:172-7.

21. Ganavadiya R, Shekar BR, Goel P, Hongal SG, Jain M, Gupta R. Comparison of anti-plaque efficacy between a low and high cost dentifrice: A short term randomized double-blind trial. Eur J Dent 2014;8:381-8

22. Veiga VF Jr, Pinto AC, Maciel MA. Medicinal plants: Safe cure? Quim Nova 2005;28:519-28.

23. Nogueira MA, Diaz MG, Tagami PM, Lorscheide J. Antimicrobial activity of essential oils and extracts of propolis against cariogenic bacteria. J Basic Applied Pharmaceutical Sciences 2007;28:93-7.

24. De Rossi A, Ferreira DC, da Silva RA, de Queiroz AM, da Silva LA, Nelson-Filho P. Antimicrobial activity of toothpastes containing natural extracts, chlorhexidine or triclosan. Braz Dent J 2014;25:186-90.

25. Almeida RB, Camaroto JL, Navarro DF, Park YK, Ikegaki M, Kozlowski VA Jr. Determination of total flavonoids in propolis samples. Publicatio UEPG Biol Health Sci 1997;3:33-41.

26. Ercan N, Erdemir EO, Ozkan SY, Hendek MK. The comparative effect of propolis in two different vehicles; mouthwash and chewing-gum on plaque accumulation and gingival inflammation. Eur J Dent 2015;9:272-6.

27. Thosar N, Basak S, Bahadure RN, Rajurkar M. Antimicrobial efficacy of five essential oils against oral pathogens: An in vitro study. Eur J Dent 2013;7 Suppl 1:S71-7.

28. Oliveira AC, Fontana A, Negrini TC, Nogueira MN, Bedran TB, Andrade CR, et al. Employment Melaleuca alternifolia oil
Cheel (Myrtaceae) in dentistry: Prospects for use as alternative antimicrobial infectious diseases of oral origin. Braz J Med Plants 2011;13:492-9.

29. Freire IC, Pérez AL, Cardoso AM, Mariz BA, Almeida LF, Cavalcanti YW, et al. Antibacterial activity of essential oils on Streptococcus mutans and Staphylococcus aureus. Braz J Med Plants 2014;16:372-7.

30. Mokrosnop VM. Functions of tocopherols in the cells of plants and other photosynthetic organisms. Ukr Biochem J 2014;86:26-36.

31. Lienau A, Glaser T, Krucker M, Zeeb D, Ley F, Curro F, et al. Qualitative and quantitative analysis of tocopherols in toothpastes and gingival tissue employing HPLC NMR and HPLC MS coupling. Anal Chem 2002;74:5192-8

32. Green AK, Alcock J, Cox TF, Abraham PJ, Savage D, McGrady M. Delivery of Vitamin E acetate and sunflower oil to gums from fluoride toothpaste containing $0.1 \%$ Vitamin E acetate and $0.5 \%$ sunflower oil. Int Dent J 2007;57:124-8.

33. Scott AE, Alcock J, Carlile MJ, Griffiths HR. Metabolism of Vitamin E acetate by reconstituted human gingival and buccal epithelium. Int Dent J 2007;57:135-9.

34. Ramos RR. Sorbitol and Oral Biochemistry. Dissertation: Master of Dental Medicine; Faculty of Dental Medicine of the Porto University, Porto; 2014.

35. Hayes $\mathrm{C}$. The effect of non-cariogenic sweeteners on the prevention of dental caries: A review of the evidence. J Dent Educ 2001;65:1106-9.

36. Petersson LG, Birkhed D, Gleerup A, Johansson M, Jönsson G. Caries-preventive effect of dentifrices containing various types and concentrations of fluorides and sugar alcohols. Caries Res 1991;25:74-9.

\begin{tabular}{|l|l|}
\hline \multicolumn{3}{|c|}{ Access this article online } \\
\hline Quick Response Code: & \\
\hline
\end{tabular}

